\title{
Analisa Pengaruh Variasi Parameter Gurdi (Drilling) Dan Pendingin Terhadap Burr Formation Hasil Pemesinan Cnc Routermilling Pada Aluminium Sheet 1100
}

\author{
Mukhlis $^{1 *}$, Bambang Dwi Haripriadi ${ }^{2 * *}$ \\ 1,2, Program studi sarjana terapan Teknik Mesin Produksi Dan Perawatan, \\ Politeknik Negeri Bengkalis, 28711, Indonesia \\ Email:*mukhlisulis1231@gmail.com,** bambang@polbeng.ac.id
}

\begin{abstract}
In the machining process, one of the things that cannot be released is the occurrence of burr formation or chip that sticks to the moment after the deduction process is carried out. To reduce burr formation is usually by determining good cutting parameters and given a cooling medium that functions to control the temperature during lubrication.This study aims to determine the burr formation on the 1100 aluminum sheet material using the machining method of milling raouter with the depth of feeding in accordance with the thickness of the workpiece. The spindle rotation used is $1200 \mathrm{rpm}$ with a variation of the cutting tool eyes that is $4 \mathrm{~mm}, 6 \mathrm{~mm}$, and $8 \mathrm{~mm}$ of the HSS tool brand and variations of the cooler namely air, coolant, oil. This research uses taguchi and ANOVA methods by measuring burr formation using USB microscope with $1200 x$ magnification. Then get the smallest burr formation value of $0.16819 \mathrm{~mm}$ with the parameter arrangement of the diameter of the drill bit $6,(f) 40 \mathrm{~mm} /$ minute, oil coolant. As for the Exit (outlet) the smallest burr formation of $0.27211 \mathrm{~mm}$ in the arrangement of the diameter of the tool diameter of the $4,(f) 50$ $\mathrm{mm} /$ minute oil cooler.
\end{abstract}

Keywords: Burr formation, Aaluminum sheet 1100, Taguchi, Anova, USB microscope

\section{PENDAHULUAN}

Gurdi (drilling) adalah proses pembuatan sebuah lubang dalam sebuah objek dengan menekankan sebuah mata pahat yang berputar pada objek tersebut. Permasalahan utama yang sering muncul dan dapat mempengaruhi kualitas hasil penggurdian antara lain perubahan kekerasan, perubahan struktur mikro. Selama proses permesinan terjadi interaksi antara mata bor dengan benda kerja dimana benda kerja terpotong sedangkan mata bor mengalami gesekan, Proses Drilling dimana "tool" atau mata bor melakukan pengeboran pada benda kerja. Dalam prosesnya mata bor atau "tool" terjadi interaksi gesekan Maka masalah yang ditimbulkan adanya perubahan kekerasan dan struktur mikro akibat gesekan yang terjadi pada Pahat/tool dengan benda kerja.dan efektifitas variasi pendingin terhadap proses drilling [1]. Adapun yang sering terjadi pada proses gurdi yaitu, (burr formation). Burr formation sebuah fenomena yang tidak menguntungkan, sering terjadi pada setiap pemesinan (cacat mesin) dimana chip atau bram yang biasa nya lepas dari permukaan tetapi pada kejadian ini chip atau bram tidak lepas atau menempel baik di saluran masuk atau keluaran. Itu juga salah satu yang paling menyusahkan hambatan untuk produktivitas tinggi dan otomatisasi dan sangat mempengaruhi kualitas bagian mesin. Untuk memastikan dengan komponen daya saing, tepat dan bebas burr toleransi ketat dan permukaan akhir yang lebih baik [2]. Burr adalah proyeksi material yang tidak diinginkan dalam sebagian besar proses pemesinan. Di bagian presisi, operasi deburring dan edge finishing dapat mencapai lebih dari $30 \%$ dari total biaya bagian yang diproduksi. Jika tidakdilepas, kontak antar serpihan dapat menjadi tidak sempurna dan menghasilkan, misalnya, pemasangan yang tidak tepat antara permukaan dan rakitan yang tidaktepat, selain menawarkan risiko kecelakaan bagi operator yang dapat terluka saat menangani bagian [3], menjelaskan mekanisme pembentukan duri dalam pengeboran. Ketika kedalaman pengeboran meningkat, deformasi yang terakumulasi di dasar lubang juga 
meningkat. Ketika nilai ini cukup untuk mencapai tegangan pecah (stress failure) dari material, fraktur dimulai pada titik deformasi yang lebih besar. Fraktur juga tergantung pada geometri bor, karena bor dengan tepi pahat besar cenderung meningkatkan gaya aksial di tengah lubang.

\section{Mesin CNC Router Milling}

Secara sistematik menjelaskan sumbu-sumbu $N C$ dimulai dengan sumbu $\mathrm{Z}$ yang beriorientasi pada spindle, diikuti dengan sumbu $X$ yang horizontal, kemudian barulah sumbu $\mathrm{Y}$ yang mengikuti kaidah tangan kanan sehingga membentuk sistem sumbu $\mathrm{X}, \mathrm{Y}$, dan $\mathrm{Z}$ untuk menyatakan translasi pahat.Dalam proses mendesain sampai membentuk benda kerja menggunakan mesin CNC router, mesin ini dioperasikan dengan menggunakan kontrol komputer dan gerakan alat pemotong diatur dalam program $N C$. Program ini berisi daftar kode yang bisa dimengerti oleh pengontrol mesin CNC. CNC Controller merupakan jantung mesin CNC yang mengendalikan sebagian besar fungsi mesin CNC. Komponen CNC Controller bertanggung jawab untuk memposisikan sinyal yang dibuat menggunakan komputer dan bekerja sama dengan perangkat lunak NC dalam pengendalian motor yang sesuai. Keseluruhan proses tersebut secara bersama me mbuat sistem kontrol total. Ada tiga komponen dasar pengendali $C N C$.1. Unit catu daya 2. Unit sistem proteksi rangkaian 3. Unit penggerak motor.

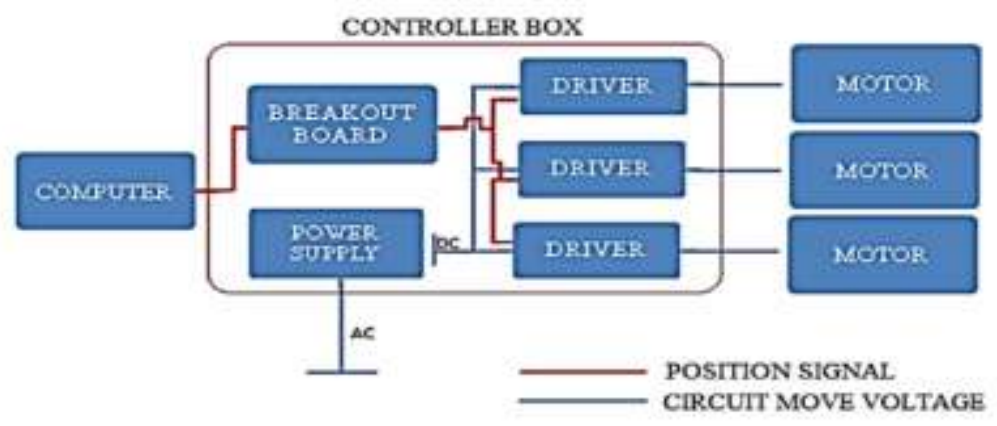

Gambar 1 Blok Diagram Controller Mesin CNC Router Milling

\section{Proses gurdi (drilling)}

Pahat gurdi adalah sebuah pahat potong yang ujungnya berputar dan memiliki satu atau beberapa tepi potong dan galur (flute) yang berhubungan kontinou disepanjang badan pahat.Galur ini dapat lurus atau heliks, yang fungsinya adalah sebagai jalan lewatnya geram dan fluida pemotong (cairan pendingin). (Rahdiyanta,2010). Meskipun pahat gurdi pada umumnya memiliki dua galur, tetapi mungkin juga digunakan tiga atau empat galur.Galur yang jumlahnya tiga atau empat tidak digunakan untuk membuat lubang melainkan digunakan untuk memperbesar lubang. Untuk lebih jelasnya twist drill dapat dilihat pada Gambar 2.2:

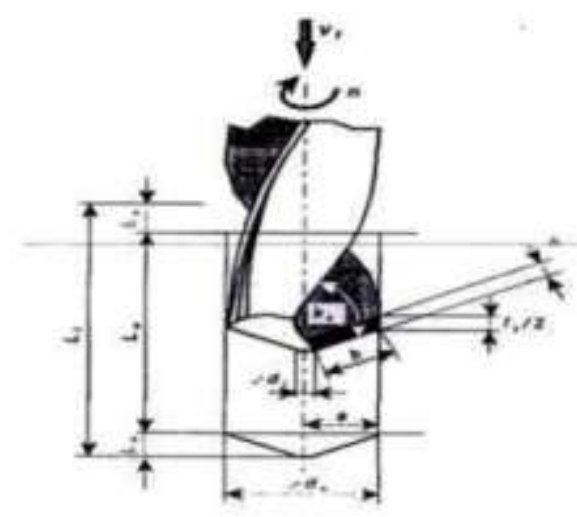

Gambar 2.Proses Drilling

Copyright $^{\circledR} 2020$ Jurnal Rekayasa Material, Manufaktur dan Energi. This is an open acces article under the CC-BY-SA lisence (https://creativecommons.org/licenses/by-sa/4.0/). 


\section{Jurnal Rekayasa Material, Manufaktur dan Energi}

\section{Burr Formation}

Burr adalah proyeksi material yang tidak diinginkan dalam sebagian besar proses pemesinan. Di bagian presisi, operasi deburring dan edge finishing dapat mencapai lebih dari $30 \%$ dari total biaya bagian yang diproduksi. Fraktur juga tergantung pada geometri bor, karena bor dengan tepi pahat besar cendrung meningkatkan gaya di tengah lubang, yang dilihat pada gambar

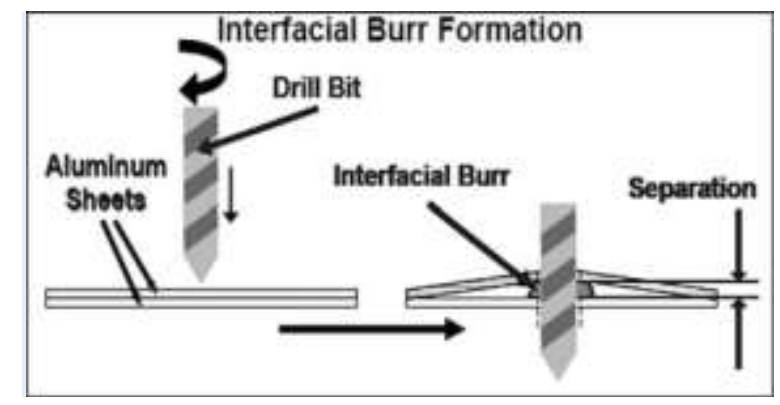

Gambar 3.Formasi Burr Interfacial dalam Pengeboran Aerospace Stacked

Micro Hole mechining merupakan peroses pembuatan lubang yang berukura yang sangat kecil (mikro) dengan drilling mechnie atau mesin bor, yang bisa disebut dengan 'pengeboran' pada proses drilling, selain menghadilkan lubang dengan diameter tertentu, selalu terbentuk burr atau benjolan-benjolan kadar pada tepi lubang masuk maupun lubang keluar, yang merupakan sisa dari hasil machning, layak nya tatal atau chip, burr merupakan bagian yang tidak diinginkan dalam suatu proses machining selain karena bentuknya yang mengurangi estetika, untuk beberapa kebutuhan burr dapat mengurangi kualitas suatu produk, mengurangi kepersisian dan daya tahan produk, menggangu dalam proses assembly sehingga harus diminimalisir bahkan dieliminasi seksistensinya jika memungkinkan [11]

\section{METODE PENELITIAN}

\section{Bahan yang digunakan}

Penelitian ini menggunakan plat aluminium sheet 1100 (ukuran $40 \mathrm{~mm}$ x $40 \mathrm{~mm}$ ). Lembaran aluminium 1100 adalah sejenis aluminium tulen industri, kandungan aluminium (pecahan jisim) sebanyak $99.00 \%$. Ketahanan korosi pada aluminium berubah menurut kemurnian, pada umumnya untuk kemurnian 99,00\% atau diatasnya dapat dipergunakan di udara tahan dalam waktu bertahuntahun.

\section{Metode Pengukuran}

Pengukuran dilakukan pada permukaan lubang hasil gurdi baik pada bagian atas maupun bawah. Pengukuranpermukaan objek dilakukan secara visual dilayar komputerKemudian burr di diukur dengan mengukur diameter lubang hasil gurdi (D) dan diameter burr farmation $\left(D_{\max }\right)$ yang dihasilkan pada proses gurdi, pengukuran dilakukan dengan mengambil data menggunakan miskroskop USB pengukuran sebanyak 10 titik pada saluran masuk dan keluar nya, baikburr yang terbentuk, kemudian diambil nilai rata-ratanya.

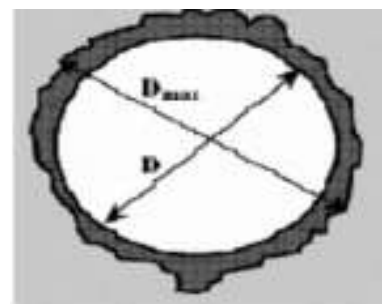

Gambar 4. Ukuran burr

Copyright ${ }^{\odot} 2020$ Jurnal Rekayasa Material, Manufaktur dan Energi. This is an open acces article under the CC-BY-SA lisence (https://creativecommons.org/licenses/by-sa/4.0/). 


\section{Jurnal Rekayasa Material, Manufaktur dan Energi}

\section{Rancangan Eksperimen Dengan Metode Taguchi}

Rancangan eksperimen ini diawali dengan pemilihan matriks ortogonal yang tergantung dari banyaknya variabel kontrol dan level dari masing-masing variabel tersebut. Tabel 3.9 menunjukkan jenis variabel bebas, jumlah level dan nilai dari variabel bebas yang digunakan pada penelitian ini.

Tabel 1. Fariabel Bebas dan Penentuan Level

\begin{tabular}{llll}
\multicolumn{1}{c}{ Parameter } & \multicolumn{1}{c}{ Level 1 } & \multicolumn{1}{c}{ Level 2 } & \multicolumn{1}{c}{ Level 3 } \\
\hline Diameter pahat gurdi $(\mathrm{mm})$ & $4 \mathrm{~mm}$ & $6 \mathrm{~mm}$ & $8 \mathrm{~mm}$ \\
Kecepatan gerak makan $\mathrm{V}_{f}$ & $30(\mathrm{~m} / \mathrm{mnt})$ & $40(\mathrm{~m} / \mathrm{mnt})$ & $50(\mathrm{~m} / \mathrm{mnt})$ \\
Pendingin & Udara & Coolant & Oli \\
\hline
\end{tabular}

Berdasarkan hasil perhitungan pada Tabel 1 didapatkan pemilihan orthogonal array design untuk rancangan eksperimen ini, sehingga matrik ortogonal yang digunakan adalah L9 $\left(3^{3}\right)$. Matrik ortogonal jenis L9 $\left(3^{3}\right)$ memiliki 3 kolom dan 9 baris yang mampu digunakan untuk tiga buah variabel bebas yang masing-masing memiliki 3 level. Rancangan eksperimen untuk penelitian ini dapat dilihat pada Tabel 2 sebagai berikut.

Tabel 2. Matrik OrtogonalL ${ }_{9}\left(3^{3}\right)$

\begin{tabular}{|c|c|c|c|}
\hline \multirow{2}{*}{ No } & \multicolumn{3}{|l|}{ Parameter } \\
\hline & Diameter pahat gurdi $(\mathrm{mm})$ & Kecepatan gerak makan $V_{f}(\mathrm{~m} / \mathrm{mnt})$ & Pendingin \\
\hline 1 & 1 & 1 & Udara \\
\hline 2 & 1 & 2 & Coolant \\
\hline 3 & 1 & 3 & Oli \\
\hline 4 & 2 & 1 & Coolant \\
\hline 5 & 2 & 2 & Oli \\
\hline 6 & 2 & 3 & udara \\
\hline 7 & 3 & 1 & oli \\
\hline 8 & 3 & 2 & udara \\
\hline 9 & 3 & 3 & coolant \\
\hline
\end{tabular}

Tabel 3. Tabel Data Dari Matrik Ortogonal L9 $\left(3^{3}\right)$

\begin{tabular}{|c|c|c|c|c|}
\hline \multirow[b]{2}{*}{ No } & \multicolumn{3}{|l|}{ Parameter } & \multirow{2}{*}{$\begin{array}{l}\text { Cacat material } \\
\text { (burr formation) }\end{array}$} \\
\hline & Diameter pahat gurdi $(\mathrm{mm})$ & $\begin{array}{l}\text { Kecepatan gerak } \\
\text { makan } V_{f}(m / m n t)\end{array}$ & Pendingin & \\
\hline 1 & 4 & 30 & udara & \\
\hline 2 & 4 & 40 & coolant & \\
\hline 3 & 4 & 50 & Oli & \\
\hline 4 & 6 & 30 & coolant & \\
\hline 5 & 6 & 40 & oli & \\
\hline 6 & 6 & 50 & udara & \\
\hline 7 & 8 & 30 & oli & \\
\hline 8 & 8 & 40 & udara & \\
\hline 9 & 8 & 50 & coolant & \\
\hline
\end{tabular}

\section{HASIL DAN PEMBAHASAN}

\section{Faktor Yang Mempengaruhi Terhadap Burr Formation}

Adapun tidak semua faktor dalam penelitian ini harus diteliti, faktor yang diteliti adalah yang sangat berpengaruh secara signifikan terhadap pada besarnya burr formation proses pemesinan 


\section{Jurnal Rekayasa Material, Manufaktur dan Energi}

CNC rauter milling pemotongan plat alumunium sheet 1100. Dari bermacam segi parameter yang digunakan diametr pahat gurdi, feeding ,cairan pendingin. hal ini sangat berengaruh dalam hasil produk yang akan dibuat berdasarkan hasil percobaan, di dapatkan 3 faktor yang paling berpengaruh pada proses pemesinan,

1. Diameter pahat gurdi ( $\mathrm{mm})$

2. Feeding $(f)$

3. Cairan pendingin

Saluran Masuk Dan Keluar
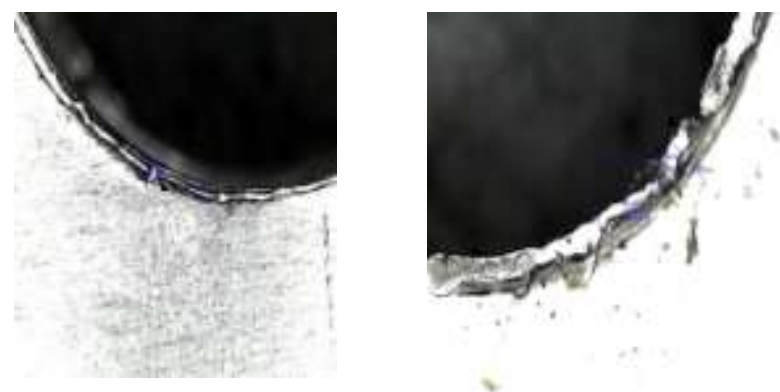

Gambar 5. burr formatiom

Tabel 4.tabel data matrik ortogonal $\mathrm{L}_{9}\left(3^{3}\right)$ saluran masuk (entrance)

\begin{tabular}{|c|c|c|c|c|}
\hline \multirow[b]{2}{*}{ No } & \multicolumn{3}{|c|}{ Parameter } & \multirow[b]{2}{*}{ Nilai Burr formation (mm) } \\
\hline & Mata bor $(\theta)$ & $\begin{array}{c}\text { Kecepatan } \\
\text { gerak makan } \\
\left(V_{f}\right) \\
\mathrm{m} / \mathrm{menit} \\
\end{array}$ & $\begin{array}{c}\text { Cairan } \\
\text { Pendingin }\end{array}$ & \\
\hline 1 & 4 & 30 & Udara & 0,26533 \\
\hline 2 & 4 & 40 & Coolant & 0,27667 \\
\hline 3 & 4 & 50 & Oli & 0,21161 \\
\hline 4 & 6 & 30 & Coolant & 0,22243 \\
\hline 5 & 6 & 40 & Oli & 0,16819 \\
\hline 6 & 6 & 50 & Udara & 0,4024 \\
\hline 7 & 8 & 30 & Oli & 0,18316 \\
\hline 8 & 8 & 40 & Udara & 0,3718 \\
\hline 9 & 8 & 50 & Coolant & 0,26144 \\
\hline
\end{tabular}

\section{Analisis Taguchi Dsign}

Dibawah ini merupakan analisa kuantitatif menggunakan program minitab 17 analisis desain taguchi. Untuk Untuk faktor kontrol dalam mengindifikasi pengaruh level dari faktor terhadap rata-rata yang digunakan saat pengeboran (gurdi) dilakukan pengeolahan data respon yang diperoleh langsung dari setiap tahap percobaan gurdi. Dibawah ini merupakan analisa kuantitatif menggunakan program minitab 17 analisis desain taguchi. Untuk mengetahui faktor apa yang paling berpengaruh dan signifikan terhadap nilai Burr formation dalam proses milling bahan alumunium sheet 1100. Didalam analisis tersebut akan ditampilkan data hasil analisis taguchi berdasarkan nilai Burr formation proses milling di setiap tahap percobaan. Dari perhitungan minitab 17 didapat kan hasil S/N Ratios dapat di lihat pada Tabel 5 sebagai berikut. 
Tabel 5. Tabel Data Hasil S/N Ratios

\begin{tabular}{|c|c|c|c|c|c|}
\hline \multirow[b]{2}{*}{ No } & \multicolumn{3}{|c|}{ Parameter } & \multirow[b]{2}{*}{$\begin{array}{c}\text { Bur } \\
\text { formation }\end{array}$} & \multirow[b]{2}{*}{ S/N Rations } \\
\hline & Mata bor & $\begin{array}{c}\text { Kecepatan gerak } \\
\text { makan }(\mathrm{Vt}) \mathrm{m} / \mathrm{mnt}\end{array}$ & $\begin{array}{c}\text { Cairan } \\
\text { Pendingin }\end{array}$ & & \\
\hline 1 & 4 & 30 & Udara & 0,26533 & 11,52427 \\
\hline 2 & 4 & 40 & Coolan & 0,27667 & 11,16076 \\
\hline 3 & 4 & 50 & Oli & 0,21161 & 13,48928 \\
\hline 4 & 6 & 30 & Coolan & 0,22243 & 13,05613 \\
\hline 5 & 6 & 40 & Oli & 0,16819 & 15,484 \\
\hline 6 & 6 & 50 & Udara & 0,4024 & 7,906841 \\
\hline 7 & 8 & 30 & Oli & 0,18316 & 14,74339 \\
\hline 8 & 8 & 40 & Udara & 0,3718 & 8,593812 \\
\hline 9 & 8 & 50 & Coolan & 0,26144 & 11,65256 \\
\hline
\end{tabular}

Perhitungan nilai S/N Ratios tergantung pada jenis karakteristik kualitas dari respon. Respon nilai burrs memiliki karakteristik kualitas semakin kecil semakin baik.S/N Ratios dari respon burr formation tersebut dihitung dengan menggunakan persamaan (4.1). Contoh perhitungan S/N Ratios dari keausan pahat untuk kombinasi setting faktor pertama dengan karakteristik kualitas semakin kecil semakin baik adalah sebagai berikut:

$$
\begin{aligned}
& \frac{\mathrm{S}}{\mathrm{N}}=-\mathbf{1 0} \log \left[\frac{\mathbf{1}}{N} \sum_{i=1}^{r} Y_{i}^{2}\right] \\
& \frac{\mathrm{S}}{\mathrm{N}}=-10 \log \left[\frac{1}{1}\left(0.26533^{2}\right)\right] \\
& \frac{\mathrm{N}}{\mathrm{S}}=-10 \log [(0.07040)] \\
& \frac{\mathrm{N}}{\mathrm{N}}=11,52427
\end{aligned}
$$

Dimana:

$N=$ jumlah replikasi data nilai burr formation yang diambil.

$Y=$ nilai burr formation yang didapatkan.

Respon Signal To Noise Ratios Smaller Is Betteruntuk faktor kontrol dalam mengindifikasi pengaruh level dari faktor terhadap rata-rata yang digunakan saat pemotongan dilakukan pengeolahan data respon yang diperoleh langsung dari setiap tahap percobaan pemotongan. Untuk respon keausan mata pahat, pengaruh level terlihat pada Tabel 6 sebagai berikut.

Tabel 6. Tabel Data Signal To Noise Ratios Smaller Is Better

\begin{tabular}{cccc}
\hline Level & diameter bor & Kecepatan gerak makan $\left(\mathrm{V}_{\mathrm{f}}\right)$ & Cairan Pendingin \\
\hline 1 & 12,058 & 13,108 & 11.956 \\
2 & 12,149 & 11,746 & 14.572 \\
3 & 11,663 & 11,016 & 9.342 \\
Delta & 0,486 & 2,092 & 5,231 \\
Rank & 3 & 2 & 1 \\
\hline
\end{tabular}

Grafik dari Signal To Noise Ratios Smaller Is Better

Berdasarkan data hasil rata-rata S/N Ratios pada hasil respon tabel diatas didapat Gambar grafik respon $\mathrm{S} / \mathrm{N}$ dapat dilihat pada Gambar dibawah ini. 


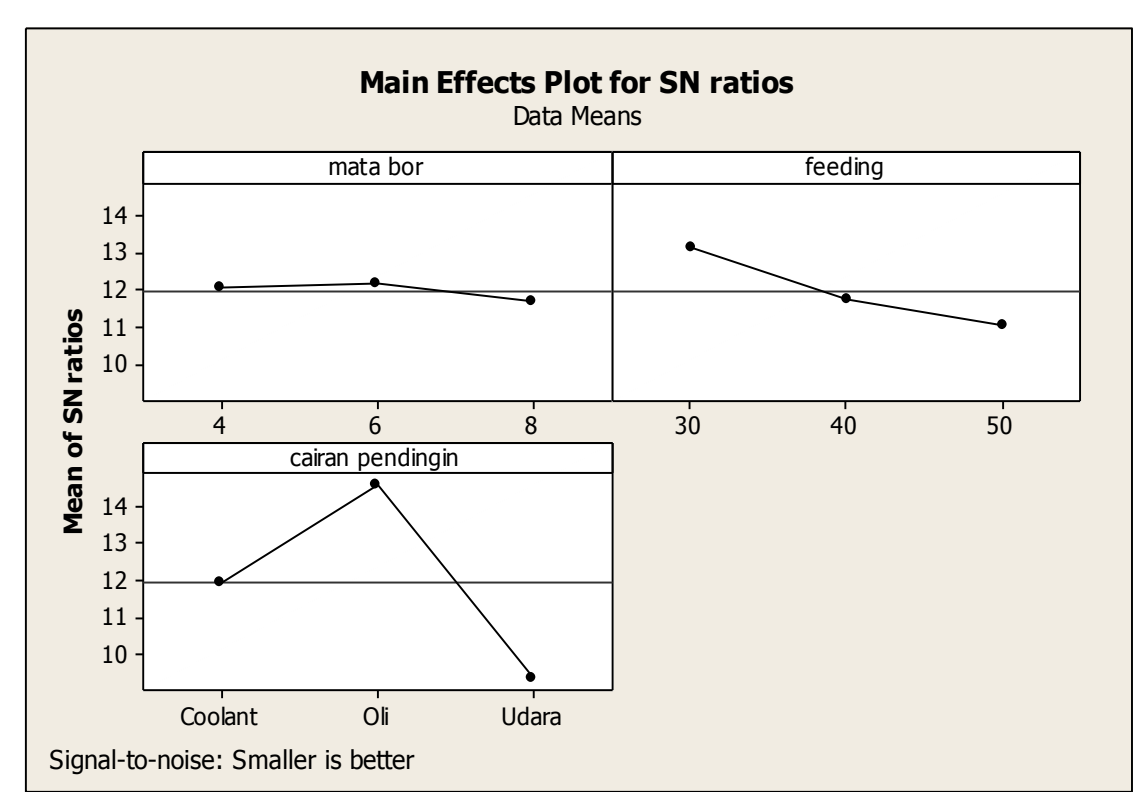

Gambar 6. Grafik Respon S/NRatios

Dilihat dari variasi parameter yang telah dilakukan, untuk variasi kecepatan gerak makan $\left(V_{f}\right)$ dan pendingin mempunyai pengaruh positif terhadap burr formation. Dapat dikatakan bahwa semakin besar Kecepatan gerak makan $\left(V_{f}\right)$, maka semakin kecil pula nilai bur formation yang terjad pada saluran masuk. Begitu juga pada variasi pendingin mempunyai pengaruh positif terhadap burr formation. Dimana semakin besar viskositas pendingin, maka semakin kecil pula nilai burr formationyang terjadi. Kondisi optimum yang didapat dengan mempergunakan analisis signal to noise ratio ( $\mathrm{S} / \mathrm{N}$ Ratios) "small is better" terhadap rancangan percobaan metode taguchi L-9 $\left(3^{3}\right)$ menunjukkan kondisi yang berbeda. Untuk rentang mata bor $(Q), 4,6,8 \mathrm{~mm},\left(V_{f}\right) 30,40$, $50 \mathrm{~mm} / \mathrm{min}$, dan pendingin udara, coolant, oli, pada rentang tersebut mampu memberikan nilai burr formation yang rendah seperti yang ditunjukkan pada Gambar diatas. Hasil ini didapat dengan mengkombinasikan mata pahat 6 , fedding $40 \mathrm{~mm} / \mathrm{min}$, pendingin oli. Kondisi gurdi ini adalah kondisi pemotongan yang baik diantara rentang kombinasi parameter pemotongan yang diamati bisa dilihat pada tabel 7

\section{Analysis Of Varian (ANOVA)}

Analysis of Varian (ANOVA) digunakan untuk mengetahui variabel proses yang memiliki pengaruh secara signifikan. Dengan menggunakan softwere minitab 17 hasil ANOVA burr formation dengan faktor mata bor, feeding dan pendingin. Maka dapat dilihat pada analisis of variance yang tampak dibawah ini

Tabel 7.Analisis Of Varian (ANOVA)

\begin{tabular}{llllll}
\hline Source & DF & Adj SS & Adj MS & F-Value & P-Value \\
\hline Diameter pahat & 2 & 0,000671 & 0,000336 & 0,14 & 0,087 \\
Kecepatan gerak makan (Vt) & 2 & 0,007392 & 0,003696 & 1,53 & 0,039 \\
Cairan pendingin & 2 & 0,038221 & 0,019111 & 7,92 & 0,011 \\
Error & 2 & 0,004828 & 0,002414 & & \\
Total & 8 & 0,051113 & & & \\
\hline
\end{tabular}

Pada analisis of variance tersebut dimana hasil pengolahan data menggunakan program minitab 17, pada kolom terakhir muncul huruf P. Itu merupakan satuan atau simbol dari nilai probabilitas (P-value), itu adalah peluang munculnya suatu kejadian. Besarnya peluang melakukan 


\section{Jurnal Rekayasa Material, Manufaktur dan Energi}

kesalahan disebut taraf signifikansi yang artinya meyakinkan atau berarti.Dalam penelitian ini mengandung arti bahwa hipotesis yang telah terbukti pada sampel dapat diperlakukan pada populasi. Tingkat signifikansi 5\% atau 0,050 artinya kita mengambil resiko kesalahan dalam mengambil keputusan untuk menolak hipotesis yang benar sebanyak-banyaknya 5\% dan dalam mengambil keputusan sedikitnya 95\% tingkat kepercayaan.[15]

Dalam penelitian ini nilai $\mathrm{P}$ untuk diameter pahat adalah 0,087 , nilai $\mathrm{P}$ untuk feeding adalah 0,039 dan nilai $\mathrm{P}$ untuk pendingin adalah 0,011 Dari data tersebut menyatakan bahwa parameter pendingin menghasilkan nilai $\mathrm{P}<0,050$, hal ini menunjukkan bahwa parameter pendingin merupakan faktor yang paling signifikan dalam mempengaruhi besarnya nilai burr formation, sedangkan untuk parameter diameter pahat dan tidak begitu signifikan karena nilai $\mathrm{P}>0,050$, bisa diartikan pengaruhnya kecil dalam mempengaruhi nilai burr formation.

\section{Uji Distribusi Normal}

Uji distribusi normal dilakukan untuk mengamati penyimpangan model.Sudah dikatakan telah mengikuti distribusi normal jika pada kurva kenormalan residual, apabila titik residual yang dihasilkan telah sesuai atau mendekati garis lurus yang ditentukan. Gambar 7 menunjukkan hasil statistik Kolmogorov-Smirnov (KS) untuk uji distribusi normal dengan derajat signifikansi $\alpha=$ 0,05 . Hipotesis:

H0 : residual model regresi berdistribusi

normal

H1 : residual model regresi tidak berdistribusi

normal.

Berdasarkan tabel statistik Kolmogorov-Smirnov untuk $a=0,05$ dan jumlah pengamatan sebanyak 9 pengamatan adalah 0,43001 . Nilai ini akan dijadikan patokan untuk mengambil kesimpulan berdasarkan hasil uji kenormalan data yang telah dilakukan. Nilai statistik Kolmogorov-Smirnov adalah 0,208. Nilai Kolmogorov-Smirnov yang diperoleh dari pengamatan kurang dari nilai tabel statistik Kolmogorov-Smirnov yaitu $0,208<0,43001$. Oleh karena itu, kesimpulan hasil uji kenormalan rasidual adalah rasidual model regresi linear yang dibuat telah mengikuti distribusi normal.Jadi asumsi asumsi kenormalan rasidual pada suatu model regresi telah dipenuhi oleh model regresi linear, sehingga model regresi yang telah dibuat bisa digunakan.Dapat dilihat pada Gambar 7.sebagai berikut.

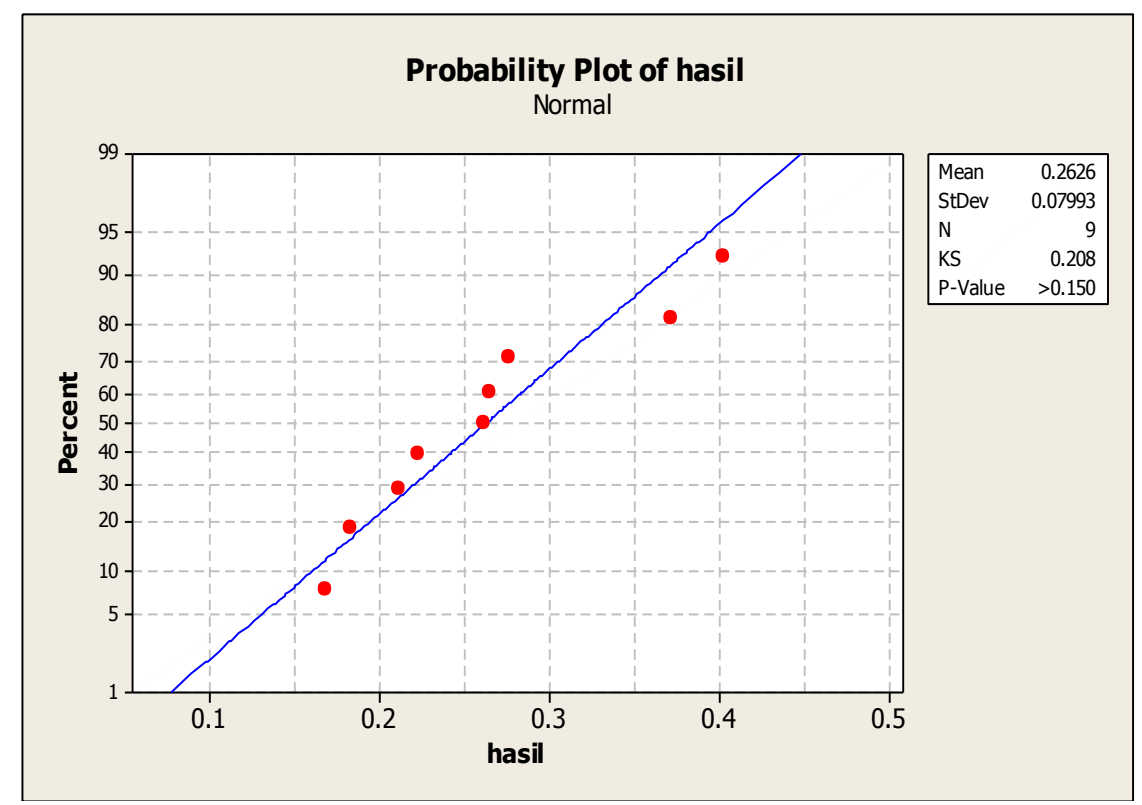

Copyright ${ }^{\odot} 2020$ Jurnal Rekayasa Material, Manufaktur dan Energi. This is an open acces article under the CC-BY-SA lisence (https://creativecommons.org/licenses/by-sa/4.0/). 
Gambar 7. Grafik Uji Kenormalan burr formation (Sumber: Dokumentasi Penelitian)

\section{Saluran Keluar (Exit)}

Sedangkan untuk Exit (saluran keluar) burr formation terkecil sebesar 0,27211 mm pada susunan parameter diameter pahat gurdi $4,\left(V_{f}\right) 50 \mathrm{~mm} /$ menit pendingin oli. Seperti terlihat pada tabel 8. dibawah ini.

$\underline{\text { Tabel 7.tabel data matrik ortogonal } \mathrm{L}_{9}\left(3^{3}\right) \text { saluran keluar (exit) }}$

\begin{tabular}{lllll}
\hline No & $\begin{array}{l}\text { Parameter } \\
\text { Diameter pahat gurdi } \\
(\mathbf{m m})\end{array}$ & $\begin{array}{l}\text { Kecepatan gerak makan }\left(\boldsymbol{V}_{\boldsymbol{f}}\right) \\
\mathbf{m} / \text { menit }\end{array}$ & $\begin{array}{l}\text { Pendingin } \\
\text { Burr formation }(\mathbf{m m})\end{array}$ \\
\hline 1 & 4 & 30 & Udara & 0,55145 \\
2 & 4 & 40 & Coolant & 0,37667 \\
3 & 4 & 50 & Oli & 0,27211 \\
4 & 6 & 30 & Coolant & 0,45536 \\
5 & 6 & 40 & Oli & 0,3745 \\
6 & 6 & 50 & Udara & 0,42906 \\
7 & 8 & 30 & Oli & 0,3725 \\
8 & 8 & 40 & Udara & 0,3718 \\
9 & 8 & 50 & Coolant & 0,36811 \\
\hline
\end{tabular}

Dari hasil percobaan berdasarkan parameter yang sudah di acak sesuai dengan program minitab 17 metode taguchi menggunakan matrik orthogonal L9 $\left(3^{3}\right)$ dapat dilihat nilai Burr terbesar untuk saluran keluar terjadi pada parameter yang pertama dengan diameter pahat $4 \mathrm{~mm}$, $\left(v_{f}\right) 30 \mathrm{~mm} / \mathrm{menit}$, dan pendingin udaradengan nilai Burr $0,55145 \mathrm{~mm}$ dan yang terkecil terjadi pada parameter ke tiga dengan diameter pahat $4,\left(v_{f}\right) 50 \mathrm{~mm} / \mathrm{menit}$ dan pendingin oli.

\section{Analisis Taguchi Design}

Kondisi ini terjadi pada alumunium sheet 1100. Hal ini diperkuat oleh hasil analisa Signal To Noise Ratio (S/N Ratio)seperti terlihat pada tabel 4.6. Perhitungan nilai S/NRatios tergantung pada jenis karakteristik kualitas dari respon. Respon burr formation memiliki karakteristik kualitas semakin kecil semakin baik,

Tabel 8.tabel data matrik ortogonal $\mathrm{L}_{9}\left(3^{3}\right)$

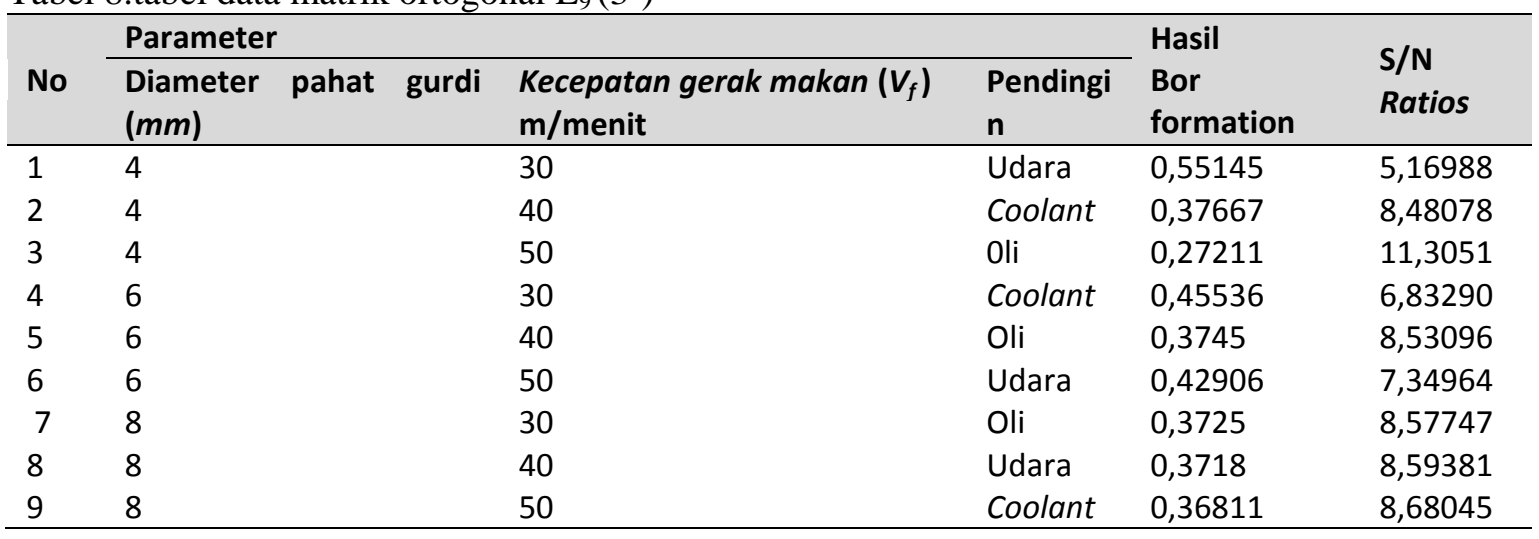

Dimana memberi pengaruh yang besar terhadap terbentuknya burr formation baik pada saluran masuk (Entrance) maupun pada saluran keluar (Exit). Contoh perhitungan $\mathrm{S} / \mathrm{N}$ Ratios dari 


\section{Jurnal Rekayasa Material, Manufaktur dan Energi}

burr formation untuk kombinasi setting faktor pertamadengan karakteristik kualitas semakin kecil semakin baik adalah sebagai berikut:

$$
\begin{aligned}
& \frac{\mathbf{S}}{\mathrm{N}}=-\mathbf{1 0} \log \left[\frac{\mathbf{1}}{\mathrm{N}} \sum_{i=1}^{r} \boldsymbol{Y}_{\boldsymbol{i}}^{2}\right] \\
& \frac{\mathrm{S}}{\mathrm{N}}=-10 \log \left[\frac{1}{1}\left(0.55145^{2}\right)\right] \\
& \frac{\mathrm{S}}{\mathrm{N}}=-10 \log [(0.304097)] \\
& \frac{\mathrm{S}}{\mathrm{N}}=5,16988
\end{aligned}
$$

Dimana:

$N=$ jumlah replikasi data nilai burr formation yang diambil.

$Y=$ nilai burr formation yang didapatkan.

\section{Respon Tabel For Signal To Noise Ratios Smaller Is Better}

Untuk faktor kontrol dalam mengindifikasi pengaruh level dari faktor terhadap rata-rata yang digunakan saat pengeboran (gurdi) dilakukan pengeolahan data respon yang diperoleh langsung dari setiap tahap percobaan gurdi. Untuk respon burr formation, pengaruh level terlihat pada hasil table 8 dibawah ini.

Tabel 8Response Table For Signal To Noise Ratios (Smaller Is Better)

\begin{tabular}{llll}
\hline Level & diameter pahat gurdi & Kecepatan gerak makan & Pendingin \\
\hline 1 & 8,319 & 6,860 & 7,998 \\
2 & 7,571 & 8,535 & 7,471 \\
3 & 8,617 & 9,112 & 9,038 \\
Delta & 1,046 & 2,252 & 2,433 \\
Rank & 3 & 2 & 1 \\
\hline
\end{tabular}

\section{Grafik Dari Signal To Noise Ratios Smaller Is Better}

Berdasarkan data hasil rata-rata S/N Ratios pada hasil respon tabel diatas didapat Gambar grafik respon $\mathrm{S} / \mathrm{N}$ dapat dilihat pada Gambar 8 sebagai berikut

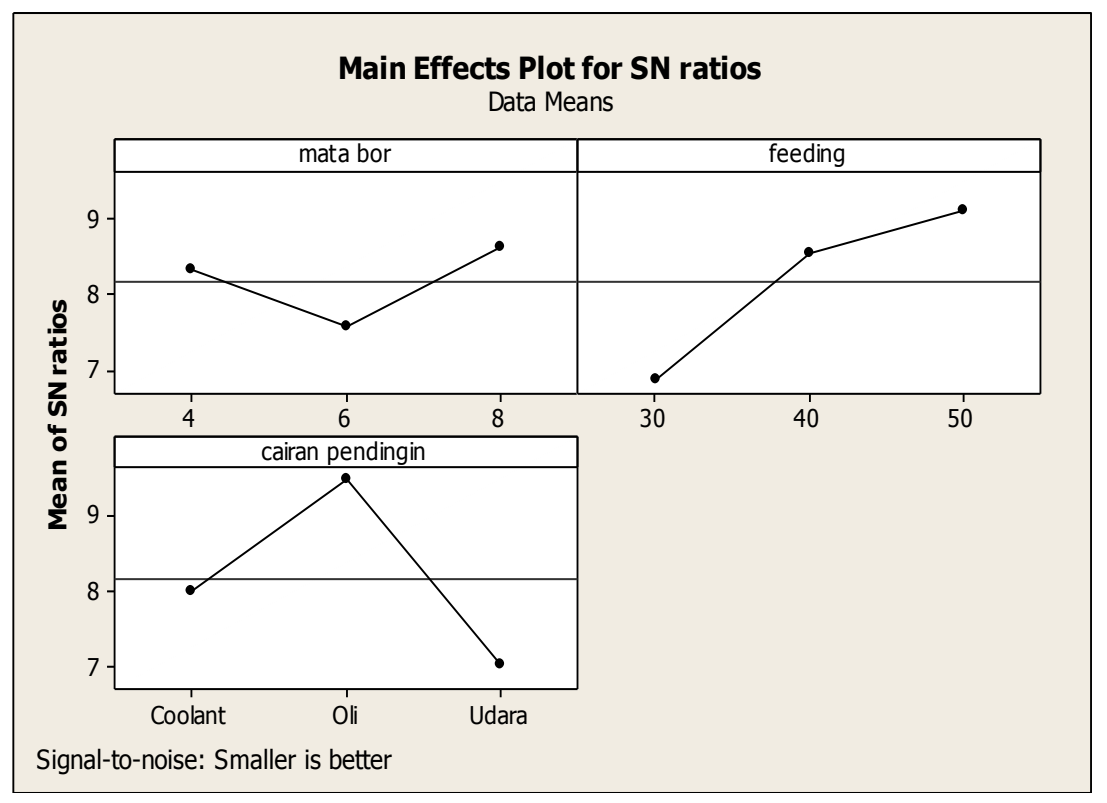

Copyright ${ }^{\odot} 2020$ Jurnal Rekayasa Material, Manufaktur dan Energi. This is an open acces article under the CC-BY-SA lisence (https://creativecommons.org/licenses/by-sa/4.0/). 
Gambar 8 grafik respon S/N (exit)

Dilihat dari variasi parameter yang telah dilakukan, untuk variasi pendingin dan $\left(v_{f}\right)$ mempunyai pengaruh positif terhadap burr formation. Dapat dikatakan bahwa semakin besar feeding $\left(v_{f}\right.$ ) maka semakin besar pula nilai bur formation yang terjadi. Begitu juga pada variasi pendingin mempunyai pengaruh positif terhadap burr formation.Dimana semakin besar viskositas pendingin, maka semakin kecil pula nilai burr formation yang terjadi. Akan tetapi bila dilihat dari pengurdian yang terjadi, apabila proses pemotongan dilakukan dengan menggunakan media pendinginan udara, maka akan timbul nilai burr formation yang cukup besar bisa dilihat pada tabel 7. Hal ini terbukti antara nilai burr formation yang menggunakan media cairan pendingin dan menggunakan media pendingin udara, jauh lebih besar burr formation yang menggunakan media pendingin udara. Sehingga burr formation jauh lebih mudah terlihat jelas dibandingkan yang menggunakan media cairan pendingin.

\section{Analysis Of Varian (ANOVA)}

Analysis of Varian (ANOVA) digunakan untuk mengetahui variabel proses yang memiliki pengaruh secara signifikan. Dengan menggunakan softwere minitab 17 hasil ANOVA burr formation dengan faktor mata bor, feeding dan pendingin. . Maka dapat dilihat pada analisis of variance untuk saluran keluar yang tampak dibawah ini.

Tabel 9Analysis of Variance

$\begin{array}{llllll}\text { Source } & \text { DF } & \text { Adj SS } & \text { Adj MS } & \text { F-Value } & \text { P-Value } \\ \text { Diameter pahat } & 2 & 0,003625 & 0,001812 & 0,57 & 0,063 \\ \text { Kecepatan gerak makan } & 2 & 0,018301 & 0,009151 & 2,86 & 0,025 \\ \text { pendingin } & 2 & 0,018550 & 0,009275 & 2,90 & 0,025 \\ \text { Error } & 2 & 0,006399 & 0,003200 & & \\ \text { Total } & 8 & 0,046875 & & & \end{array}$

Pada analisis of variance tersebut dimana hasil pengolahan data menggunakan program minitab 17, pada kolom terakhir muncul huruf P. Itu merupakan satuan atau simbol dari nilai probabilitas (P-value), itu adalah peluang munculnya suatu kejadian. Besarnya peluang melakukan kesalahan disebut taraf signifikansi yang artinya meyakinkan atau berarti.Dalam penelitian ini mengandung arti bahwa hipotesis yang telah terbukti pada sampel dapat diperlakukan pada populasi. Tingkat signifikansi 5\% atau 0,050 artinya kita mengambil resiko kesalahan dalam mengambil keputusan untuk menolak hipotesis yang benar sebanyak-banyaknya 5\% dan dalam mengambil keputusan sedikitnya 95\% tingkat kepercayaan.[15]

Dalam penelitian ini nilai $\mathrm{P}$ untuk diameter pahat adalah 0,063 , nilai $\mathrm{P}$ untuk feeding adalah 0,025 dan nilai $\mathrm{P}$ untuk cairan pendingin adalah 0,025 Dari data tersebut menyatakan bahwa parameter kecepatan gerak makanmenghasilkan nilai $\mathrm{P}<0,050$, hal ini menunjukkan bahwa parameter kecepatan gerak makan dan pendingin merupakan faktor yang paling signifikan dalam mempengaruhi besarnya nilai burr formation, sedangkan untuk parameter diameter pahat dan tidak begitu signifikan karena nilai $\mathrm{P}>0,050$, bisa diartikan pengaruhnya kecil dalam mempengaruhi nilai burr formation.

\section{Uji Distribusi Normal}

Uji distribusi normal dilakukan untuk mengamati penyimpangan model.Sudah dikatakan telah mengikuti distribusi normal jika pada kurva kenormalan residual, apabila titik residual yang dihasilkan telah sesuai atau mendekati garis lurus yang ditentukan. Gambar 4.5 menunjukkan hasil statistik Kolmogorov-Smirnov (KS) untuk uji distribusi normal dengan derajat signifikansi $\alpha=$ 0,05. Hipotesis:

H0 : residual model regresi berdistribusi

normal 
H1 : residual model regresi tidak berdistribusi normal.

Berdasarkan tabel statistik Kolmogorov-Smirnov untuk $a=0,05$ dan jumlah pengamatan sebanyak 9 pengamatan adalah 0,43001. Nilai ini akan dijadikan patokan untuk mengambil kesimpulan berdasarkan hasil uji kenormalan data yang telah dilakukan. Nilai statistik Kolmogorov-Smirnov adalah 0,271. Nilai Kolmogorov-Smirnov yang diperoleh dari pengamatan kurang dari nilai tabel statistik Kolmogorov-Smirnov yaitu $0,271<0,43001$. Oleh karena itu, kesimpulan hasil uji kenormalan rasidual adalah rasidual model regresi linear yang dibuat telah mengikuti distribusi normal.Jadi asumsi asumsi kenormalan rasidual pada suatu model regresi telah dipenuhi oleh model regresi linear, sehingga model regresi yang telah dibuat bisa digunakan.Dapat dilihat pada Gambar 4.6 sebagai berikut.

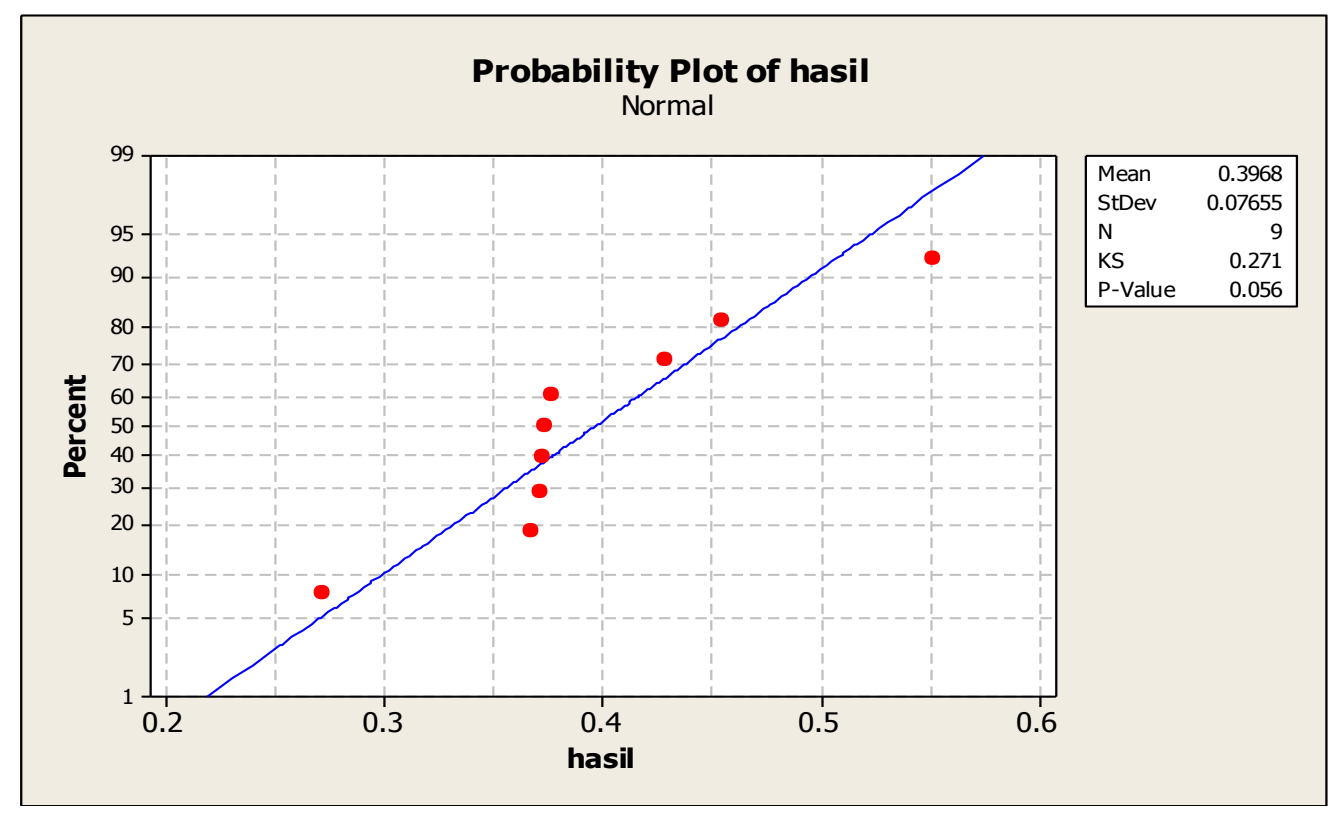

Gambar 9. Grafik Uji Kenormalan burr formation (Sumber: Dokumentasi Penelitian)

\section{KESIMPULAN DAN SARAN}

\section{Kesimpulan}

Berdasarkan hasil eksperimen dan analisis yang telah dilakukan, maka penelitian yang berjudul "Analisa Pengaruh Variasi Parameter Gurdi (Drilling) Dan Pendingin Terhadap Burr Hasil PemesinanCnc Router Milling Pada Aluminium Sheet 1100" dapat diambil kesimpulan sebagai berikut:

1. Dari hasil percobaan berdasarkan parameter yang sudah di acak sesuai dengan program minitab 17 metode taguchi menggunakan matrik orthogonal L9 $\left(3^{3}\right)$ dapat dilihatburr formation terkecil sebesar $0,16819 \mathrm{~mm}$ dengan susunan parameter diameter mata bor $6,\left(v_{f}\right)$ $40 \mathrm{~mm} / \mathrm{menit}$, pendingin oli.

2. Dari hasil percobaan berdasarkan parameter yang sudah di acak sesuai dengan program minitab 17 metode taguchi menggunakan matrik orthogonal L9 $\left(3^{3}\right)$ dapat dilihat nilai Burr terbesar untuk saluran keluar terjadi pada parameter yang pertama dengan diameter pahat 4 $\mathrm{mm}$, feeding $30 \mathrm{~mm} / \mathrm{menit}$, dan pendingin udaradengan nilai Burr $0,55145 \mathrm{~mm}$ dan yang terkecil terjadi pada parameter ke tiga dengan diameter pahat $4,\left(v_{f}\right) 50 \mathrm{~mm} / \mathrm{menit}$ dan pendingin oli. 
3. Untuk faktor kontrol dalam mengindifikasi pengaruh level dari faktor terhadap rata-rata yang digunakan saat pemotongan dilakukan pengeolahan data respon yang diperoleh langsung dari setiap tahap percobaan pemotongan. Untuk respon nilai burr formation, rank pertama pada cairan pendingin, rank kedua kecepatan gerak makan, rank ketiga diameter pahat begitu juga dengan saluran keluar.

4. Dalam penelitian ini nilai $\mathrm{P}$ untuk diameter pahat adalah 0,087 , nilai $\mathrm{P}$ untuk kecepatan gerak makan adalah 0,39 dan nilai $\mathrm{P}$ untuk pendingin adalah 0,011 Dari data tersebut menyatakan bahwaparameter pendingin menghasilkan nilai $\mathrm{P}<0,050$, hal ini menunjukkan bahwa parameter pendingin dan feeding merupakan faktor yang paling signifikan dalam mempengaruhi besarnya nilai burr formation, sedangkan untuk parameter diameter pahat dan tidak begitu signifikan karena nilai $\mathrm{P}>0,050$, bisa diartikan pengaruhnya kecil dalam mempengaruhi nilai burr formation. Dan untuk saluran keluar adalah 0,0638, nilai P untuk feeding adalah 0,0259 dan nilai $\mathrm{P}$ untuk cairan pendingin adalah 0,0256 Dari data tersebut menyatakan bahwaparameter kecepatan gerak makan menghasilkan nilai $\mathrm{P}<0,050$, hal ini menunjukkan bahwa parameter kecepatan gerak makan dan pendingin merupakan faktor yang paling signifikan dalam mempengaruhi besarnya nilai burr formation, sedangkan untuk parameter diameter pahat dan tidak begitu signifikan karena nilai $\mathrm{P}>0,050$, bisa diartikan pengaruhnya kecil dalam mempengaruhi nilai burr formation.

5. Uji distribusi normal dilakukan untuk mengamati penyimpangan model. Sudah dikatakan telah mengikuti distribusi normal jika pada kurva kenormalan residual, apabila titik residual yang dihasilkan telah sesuai atau mendekati garis lurus yang ditentukan dapat disimpulkan bahwa uji bersifat normality test burr formation dengan statistik KolmogorovSmirnov telah terpenuhi, mengindikusikan bahwa seluruh data yang didapat penelitian ini tersebar secara merata di garis linier perkiraan, tidak ada outliers atau kemungkinan kesalahan data.

\section{DAFTAR PUSTAKA}

[1] Agus Duniawan.(2010) Jurusan Teknik Mesin Institut Sains \& Teknologi AKPRIND Yogyakarta Jl.Kalisahak no.28 Kompl. Balapan, Yogyakarta Pengaruh Variasi Kecepatan Potong Pahat Hss Pengeboran Baja S45c/Aisi 1045 Terhadap Media Pendingin Pada Uji Kekerasan Dan Stuktur Mikro

[2] Seyed Ali Niknam and Victor Songmene. (2014) Milling burr formation modeling and control: A review:_ImechE 2014,229(6)893-909

[3] Bordinassi, EC, Almeida Filho, CO C, Filho, MS e Batalha, GF, 2004-b, "Mengontrol Rebarbação e de Forças de Corte" [Kontrol pengurutan dan pemotongan], Máquinas $e$ Metais , Editora Aranda, September, pp 104119, [Dalam Bahasa Portugis

[4] Min, S., Kim, J., Dornfeld, DA, 2001, "Pengembangan Diagram Kontrol Pengeboran Pengeboran untuk Baja Paduan Rendah, AISI 4118", Jurnal Teknologi Pengolahan Bahan, Vol. 113, hal 4-9.

[5] Arifin, D.A.P., (2016) “ Rancang Bangun Bagian Dinamis Mesin Cnc Router Milling “. Universitas Jember, Jember.

[6] Rasyid, M., dkk. (2009) "Makalah Alumunium Murni Dan Paduan". Institut Pertanian Bogor, Bogor.

[7] Rochim, Taufiq. (1993) “Teori \& Teknologi Proses Pemesinan”.Higher Education Development Support Project.

[8] Pahat gurdi driling (Twist Drill) Penulis Andhy Rinanto Diterbitkan Sabtu,Juli07, 2012

[9] Rizaldi, R., (2017). "Evaluassi Unjuk Kerja Tiga Jenis Hasil Ekstraksi Santan Kelapa Sebagai Cairan Pendingin Terhadap Kekasaran Permukaan Pada Proses Bubut". Universitas Andalas, Padang.

[10] Newton. T.R dkk, (2009) Interfacial Burr Formation in Drilling of Stacked AerospaceMaterials 
[11] Aziz M dkk, Februari 27, 2017 "Innovative Micro Hole Machining with Minimum Burr Formation by The Use of Newly Developed Micro Compound Tool"

[12] Bambang Dwi Haripriadi(2018) pengaruh parameter pemotongan dan variasi susunan serat terhadap terbentuknya delaminasi pada proses menggurdi material komposit serat nenas

[13] Muhammad Rahmat, Bambang Dwi Haripriadi,(2019)" Jurusan Teknik Mesin, Prodi D-IV Teknik Mesin Produksi Dan Perawatan, Politeknik Negeri Bengkalis Analisa PengaruhVariasi Parameter Pemotongan Dan Pendingin Terhadap Tingkat Keausan Pahat End Mill Hss Hasil PemesinanCnc RouterMilling Pada AluminiumSheet 110

[14] Farid Urbeyani, (2019)" Jurusan Teknik Mesin, Prodi D-IV Teknik Mesin Produksi Dan Perawatan, Politeknik Negeri Bengkalis, pengaruh paremeter burr formation

[15] Ibrahim, G.A., Iskandar, J., Hamni, A., dan Lestari, S.M.P., (2017) “ Analisa Keausan Pahat Pada Pemesinan Bor Magnesium AZ31 Menggunakan Metode Taguchi”. Universitas Lampung, Lampung.

[16] Prianto, E., dan Pramono, H.S., (2017) "Proses Permesinan CNC Dalam Pembelajaran Simulasi CNC". Universitas Negeri Yogyakarta, Yogyakarta.

[17] http://stfajarptm.blogspot.com/2015/05/tool-twist-drill.html

[18] http://anita-widynugroho.blogspot.com/2012/04/scanning-electron-microscope-sem.html jam 23:00 wib 